\title{
Effect of Current Assets on Profit Through Credit on Jakarta Islamic Index Company 2012-2014 In Indonesia Stock Exchange
}

\author{
Agus Edi Kusuma \\ Management Studies Program \\ Faculty of Economics, University of Muhammadiyah Gresik \\ J1 Sumatera 101 GKB Gresik East Java Indonesia \\ agusedi_k@gmail.com \\ Rahmat Agus Santoso \\ Management Studies Program \\ Faculty of Economics, University of Muhammadiyah Gresik \\ J1 Sumatera 101 GKB Gresik East Java Indonesia \\ ra_rantoso@umg.ac.id \\ Anita Handayani \\ Management Studies Program \\ Faculty of Economics, University of Muhammadiyah Gresik \\ J1 Sumatera 101 GKB Gresik East Java Indonesia \\ Anita.handayani@umg.ac.id
}

Received: April 19, 2018 Accepted: May 27, 2018 Published: May 29, 2018

doi: 10.5296/jsss.v5i2.13025 URL: http://doi.org/10.5296/jsss.v5i2.13025 


\section{Abstract}

Companies in essence is to obtain the maximum profit. In theory of financial statements, profitability is a measure of the company in generating profits (the bigger the better). The profits are used to measure company performance. This study aimed to test the current asset of the Debt on the Company's Profits at the Jakarta Stock Exchange Index.This study uses a sample of 14 financial statements and tested using the t-test, sobel test and path analysis. Result of testing by t-test shows that the significant effect of Current Assets to Debt, Current Assets had no significant effect on Profits, and Debt significant effect on Profits. The result of sobel test shows Current Assets of a significant effect on Profits through Debt.The result of path analysis on line $1(\mathrm{p} 1)$ that the Current Assets of the Debt of -0.001 indicates that the current Assets of the Profits of 0.030 (p3) that the Debt of the Profits of 36.653 indicates that the higher the Debt, the Profits will be as high as well and in line 4 (p4 ) Current Assets of the Profits through Debt of -0.0006653 show that any improvement Current Assets and Debt, it will cause Profits to fall.

Keywords: Current Assets (Current Ratio), Debt (Debt to Asset Ratio), Profits (Return on Assets Ratio)

\section{Introduction}

The capital market is an important element that provides benefits to economic progress through the development of investment in a country. In this case the capital market has a strategic role in the economy of a country where the capital market can serve as an indicator of a growing country. Increasing the economy of a country can be reflected in the increase in trading volume activity in the capital market. So that the rise of the economy of a country can be reflected from the condition of the capital market in that country. One of the main functions of the capital market is as a means to mobilize funds sourced from communities to various sectors that implement investments. For people who have more funds to invest, capital markets can be an alternative to invest funds (Yulianti, 2014, 2-3). The growth of Indonesian Capital Market (IHSG) continues to grow, since 2009 growth of JCI has risen $4.56 \%, 2010$ increased by $2.99 \%, 2011$ increased by $0.39 \%$ in 2012 by $0.92 \%$, in 2013 by $0.20 \%$, and in $20141.73 \%$ (www.idx.co.id, 2016).

Along with the increasing of JCI trading activity, society and investor need relevant information about stock market development condition.Currently the Indonesia Stock Exchange has 11 types of stock index indices, such indices include: Composite Stock Price Index (IHSG), Sectoral Index, LQ45 Index, Jakarta Islamic Index (JII), Compass 100 Index, BISNIS-27 Index, PEFINDO 25, SRI-KEHATI Index, Main Board Index, Development Board Index, and Individual Index. The sectoral index of BEI is a sub-index of JCI 5 (Yulianti, 2014, 3-4).

Every issuer on the Indonesia Stock Exchange will report its finances to the public. One of them is JII (Jakarta Islamic Index ).JII refers to 30 shares whose business sectors comply with Sharia principles. Shares entering into JII must meet the same elements as other indices except for illicit elements in MUI's view. The unlawful elements required by the National Sharia Council (DSN) of MUI are generally related to business activities, ie not doing business related activities: Alcohol, Gambling, Production with raw materials of pig, 
Pornography, Financial Services and Conventional Insurance. To select the shares worthy of being a member of JII, special selection is made.

JII index is dynamic in the sense of periodically updated to be always responsive to market movements and in accordance with sharia.Every six months (January and July) the JSX will make a comeback and announce a list of new JII members. Investors can use JII as a benchmark to measure investment portfolio performance in sharia stocks (www.idx.co.id, 2016).

Ratno $(2014,6)$ explains each company in essence is to get the maximum profit. In the theory of financial statements, profitability is a measure of the firm in generating profits (the greater the better). The amount of profit used to measure the performance of the company. Analysis of the profitability ratios is very important for all users, especially equity investors and creditors investors. For equity investors, profit is the only determinant of changes in the value of securities (securities).And for creditor investors, operating income and cash flows are generally the source of interest and principal payments (John, 2005; 10).

The management of the company's assets takes a very serious attention by the company, which is related to decision making. It is expected, because well-managed assets and a small debt of existing assets will help increase profits, and as a manager's duty to calculate the amount of profits that a company can earn and to be paid for the company's debt (Mansur, $2015 ; 1)$.

Business phenomenon that occurred in JII company 2012-2014 shows profitability ( Return on Asset ) has decreased every year presented in Figure 1 below:

Source: Jakarta Islamic Index (JII), www.idx.co.id (processed data)

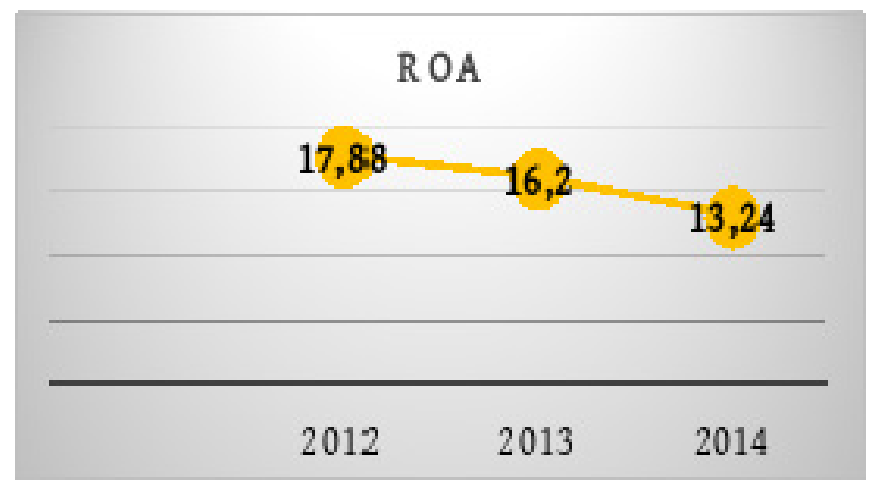

Figure 1. ROA ( Return on Asset ) at JII Company Year 2012-2014

ROA ( Return on Asset ) in the JII company in the graphic image above has decreased every year, this is certainly not expected either by the owners of the company and the investors .Munawir (2002: 89) argues that the greater the value of ROA means that a company has a good performance in generating net income for total assets acquisition so that the effect on stock prices (stock prices rise), stock price increase is an indicator of future prospects as well otherwise. Sartono $(2010 ; 122)$ states if profitability increases then the dividend will increase, so investors will be more interested to invest. 
Researchers link the results of financial statements on how the effect of current assets to earnings. Dewi (2015) examines the "Influence of LDR, LAR, DER and CR against ROA in banking companies listed on IDX Year 2011-2013", the result of this study states that current assets are partially significant and negative to profit. On the other hand Barus (2013) examines "Analysis of Factors Affecting Profitability in Manufacturing Companies Listed on the Stock Exchange", the results of this study stated that current assets have no significant effect on earnings. From the above statement there is an interesting research gap for further investigation.

The research conducted by Yesi (2013) under the title " The Influence of Current Ratio, Net Working Capital Turnover and Debt to Asset Ratio to ROA in Property and Real Estate Companies Listed on BEI Period 2008-2012" obtained debt result significantly and negative to profit .In this study can be inferred debt has a significant effect on profit, this is in accordance with the theory of James C.Van Horne and John M.Machowicz (2005: 313) in his book the principles of financial management which says that his ability to earn profits is inversely proportional to debt. The greater the proportion of debt to the capital structure of an enterprise, the higher the fixed burden and repayment commitment incurred (John, 2005; 122).

Reni (2014) examines "The Influence of Gross Profit Margin, Return on Equity, Earning Per Share and Current Ratio to Capital Structure (DER) in Manufacturing Companies Listed on Indonesia Stock Exchange Year 2010-2012", the results of this study indicate that there is significant and positive between liquidity to solvency.The greater the current assets, the greater the company's ability to meet its short-term obligations (Rahmawati, 2011; 24). This shows that the company is placing large funds on the current assets side. The placement of funds that are too large on the asset side has two different sides. On the one hand, the company's debt gets better, on the other hand the company loses the opportunity to earn extra profit. The solvency ratio is a ratio that describes a company's ability to pay its long-term liabilities or obligations if the company is liquidated (Syafri, 2005 in Marina, 2016, 24-25).

Based on this background, the researcher is interested to conduct research entitled "The Influence of Current Assets on Profit through Debt at Jakarta Islamic Index Company 2012-2014 in Indonesia Stock Exchange".

The hypothesis states the logically suspected relationship between two or more variables in the formulation of an empirically verifiable proposition (Indrianto and Supomo (2002) in Marina $(2016,25)$ ), then from the theoretical description can be raised the following research hypothesis:

Hypothesis 1: Suspected No Effect current assets (Current Ratio) to debt (Debt to Asset Ratio) at JII company in Indonesia Stock Exchange Year 2012 to 2014.

Hypothesis 2: Suspected Influence of Current Ratio ( Return on Asset Ratio ) at JII company in Indonesia Stock Exchange Year 2012-2014.

Hypothesis 3: Suspected there is Debt to Asset Ratio to earnings ( Return on Asset Ratio ) at JII company in Indonesia Stock Exchange Year 2012-2014.

Hypothesis 4: Suspected No Effect current assets (Current Ratio) to profit (Return on Assets Ratio) through debt (Debt to Asset Ratio) at JII company in Indonesia Stock Exchange Year 
2012 to 2014.

The conceptual framework in this study is presented in Figure 2 as follows:

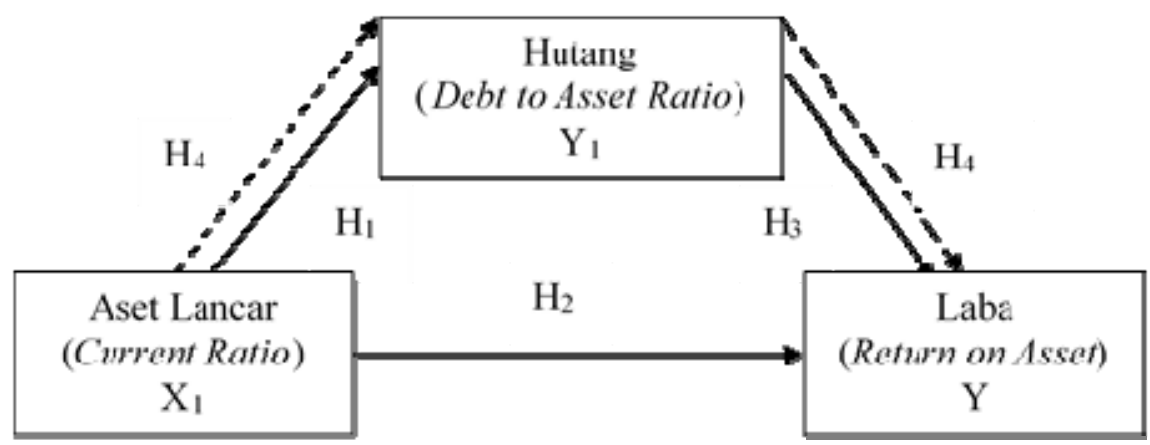

Figure 2. Conceptual famework

\section{Methodology}

The approach taken is to use quantitative methods, namely research that requires the use of numbers, ranging from data collection, interpretation of the data, and the appearance of the results.Similarly, at the conclusion of the study would be better if accompanied by images, tables, graphics, or other display (Arikunto, 2010; 27).

The research location is at the Jakarta Islamic Index stock index in the official website of the Stock Exchange www.idx.co.id. The population of this research is 44 issuers on Jakarta Islamic Index stock index which is 30 emiten every semester from semester 1 (December 2011 - May 2012) up to semester 2 (June 2014 - November 2014).Nursalam (2013: 171) states that the sample is part of the number and characteristics possessed by that population, or a small portion of the population members taken according to certain procedures so as to represent the population.

Sample selected in this research using purposive sampling method by using criteria presented in Table 1 below:

Table 1. Sample criteria for research

No. Sample Criteria

amount

1. JII Company listed on BEI three consecutive years from 2012-2014

2. Companies that earn a three-year profit in a row from 2012-2014

3. Companies that are distributing dividends for three consecutive years from 14 2012-2014

The type of data used in this study is documentary data. Indrianto and Supomo (2002) in Marina $(2016 ; 29)$ explain the documentary data is a type of data that contains what and when an event or transaction, and who is involved in an event. 


\section{Macrothink}

Source of data used in this research is secondary data. Supardi (2013: 16) says secondary data is data obtained or collected from existing sources. The data is usually obtained from libraries or from previous research reports / documents. Secondary data is also called data available. Secondary data in this research include Current Ratio, Debt to Asset Ratio and Return on Asset for the period 2012-2014 at JII Company of Indonesia Stock Exchange.

In this research, data collection is done by downloading data from the official website of Indonesia Stock Exchange (BEI) on Jakarta Islamic Index Index Shares in the financial statements for 2012-2014 period in www.idx.co.id

Operational variables and analysis and data processing is facilitated by explanation of each variable as in table 2 ,

Table 2. Operational definition of variables

\begin{tabular}{|c|c|c|c|c|c|}
\hline no & Variabel & $\begin{array}{l}\text { Alat } \\
\text { Ulkur }\end{array}$ & $\begin{array}{c}\text { Definisi } \\
\text { Operasional }\end{array}$ & RUMUS & SKALA \\
\hline 1 & $\begin{array}{l}\text { Aset } \\
\text { Lancar }\end{array}$ & $\mathrm{CR}$ & $\begin{array}{l}\text { Cwrint Ratio } \\
\text { merupakan rasio } \\
\text { yang digunakan } \\
\text { untuk mengukar } \\
\text { kemampuan } \\
\text { perugahaan dalam } \\
\text { membayar } \\
\text { kewajiban jangka } \\
\text { pendelanya } \\
\text { dengan } \\
\text { menggunakan } \\
\text { aktiva lancar yang } \\
\text { dimiliki. }\end{array}$ & $\frac{\text { Alktiva Lancar }}{\text { Hutang Lancar }} \times$ ioos & Rasio \\
\hline 2 & Laba & ROA & $\begin{array}{l}\text { ROA merupalcan } \\
\text { rasio yang } \\
\text { digunakan untuk } \\
\text { mengukar } \\
\text { kemampuan } \\
\text { perugahaan dalam } \\
\text { menghasillcan } \\
\text { laba berdasarkan } \\
\text { tingkat aset } \\
\text { tertentu, }\end{array}$ & $\frac{\text { Laba Bersih }}{\text { Total Aktiva }} \times 100 \%$ & Ragio \\
\hline 3 & Hutang & DAR & $\begin{array}{l}\text { DAR merupakan } \\
\text { rasio hutang atas } \\
\text { aset yang } \\
\text { digunakan untuk } \\
\text { menumjukkan } \\
\text { gejauh mana } \\
\text { hutang dapat } \\
\text { ditunupi oleh aget. }\end{array}$ & $\frac{\text { Total Hutang }}{\text { Total Aget }} \times$ 1004 & Ragio \\
\hline
\end{tabular}


Analytical technique that can be used in this research is using path analysis.Before conducting the analysis, the researcher used descriptive statistics to provide information on the characteristics of research variables, especially regarding the mean and standard deviation.Mean measurement is the most commonly used way to measure the central value of a data distribution.

Ghozali (2013: 19) states that descriptive statistics provide an overview or description of data seen from mean, standard deviation, variance, maximum, minimum, sum, range, kurtosis and skewness .

\section{Classic assumption test}

Multiple linear regression models can be called as good models if the model is free of static classical assumptions. This testing process uses Statistical Package for Social Sciences (SPSS).

\section{Normality test}

Normality test is used to test whether in regression model, independent variable and dependent variable or both have normal distribution or not.A good regression model is to have normal or near-normal data distribution. Normality test used in this study is kolmogorov smirnov test .

\section{Autocorrelation Test}

Autocorrelation test aims to test whether in a linear regression model there is correlation between residual errors in period $\mathrm{t}$ with error in period $\mathrm{t}-1$ (previous). Test that can be done is Durbin - Watson test .

\section{Heterocedasticity Test}

Heterokedastisitas test aims to determine whether or not the relationship between confounding variables with independent variables. The test that can be done is Glejser test.

\section{Multicollinearity Test}

This study used multicollinearity test in which the test showed more than one perfect linear relationship or between independent variables occurred correlation.

\section{Path Analysis ( Path Analysis )}

Path analysis is a multiple linear regression development technique. Technique This is used to test the amount of contribution (contribution) shown by the coefficient lines on each chart the path of the causal relationship between variables $\mathrm{X}_{1}, \mathrm{X}_{2}$ and $\mathrm{X}_{3}$ to $\mathrm{Y}$ and its impact on $\mathrm{Z}$ (Supardi, 2013; 271).

Ghozali (2013: 249) states the influence of intervening variables is known using path analysis method. Path analysis (path analysis) is an extension of the multiple linear regression analysis, or analysis of the track is the use of regression analysis to estimate the causal relationships between variables (model casual) predetermined based on the theory.

The equation model of path analysis in this study are as follows:

$\mathrm{P} 1: \mathrm{Y}_{1}=\beta_{0}+\beta_{1} \mathrm{X}_{1}+\mathrm{e}_{1}$

$\mathrm{P} 2, \mathrm{P} 3$, and $\mathrm{P} 4: \mathrm{Y}=\beta_{0}+\beta_{2} \mathrm{X}_{1}+\beta_{3} \mathrm{Y}_{1}+\beta_{4} \mathrm{X}_{1} \mathrm{Y}_{1}+\mathrm{e}_{2}$ 
The model of path analysis equation is presented in Figure 3 below:

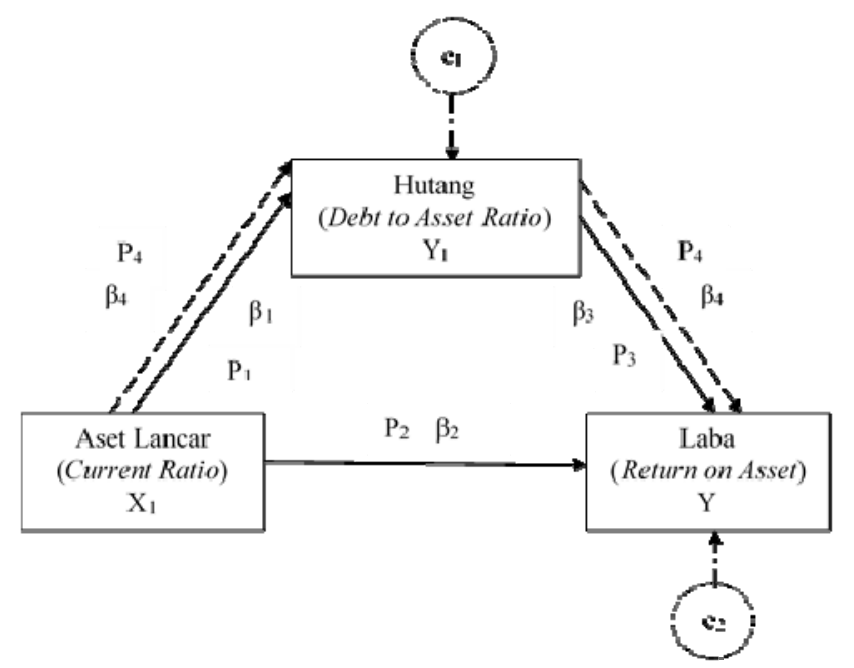

Figure 3. Path Analysis ( Path Analysis )

\section{Hypothesis testing}

Hypothesis test in this research uses $t$ test to test exogenous or dependent variable (Y) to endogenous or independent variable $(\mathrm{X})$ and test of sobel to test indirect effect independent variable $(\mathrm{X})$ to dependent variable $(\mathrm{Y})$ through intervening variable ) described as follows:

1. Hypothesis 1 or line test $1(\mathrm{p} 1)$

$\mathrm{H}_{0}=$ Current Ratio does not affect Debt to Asset Ratio in JII Company in Indonesia Stock Exchange Year 2012-2014.

$\mathrm{H}_{\mathrm{a}}=$ Current Ratio ( Debt to Asset Ratio ) in JII Company in Indonesia Stock Exchange Year 2012-2014.

Criteria for probability decision making (significance) with $\alpha=0.05$ :

a. If the probability is $>\alpha 0.05$ then $\mathrm{H}_{0}$ is accepted and $\mathrm{H}_{\mathrm{a}}$ is rejected, meaning Current Asset ( Ratio ) has no effect on Debt ( Debt to Asset Ratio ).

b. If the probability is $<\alpha 0.05$ then $\mathrm{H}_{0}$ is rejected and $\mathrm{H}_{\mathrm{a}}$ is accepted, meaning Current Asset ( Ratio ) has an effect on Debt ( Debt to Asset Ratio ).

2. Hypothesis 2 or line 2 testers (p2)

$\mathrm{H}_{0}=$ Current assets ( Current Ratio ) has no effect on earnings ( Return on Asset Ratio ) at JII company in Indonesia Stock Exchange Year 2012-2014.

$\mathrm{H}_{\mathrm{a}}=$ Current assets ( Current Ratio ) effect on profit ( Return on Asset Ratio ) at JII company in Indonesia Stock Exchange Year 2012-2014.

Criteria for probability decision making (significance) with $\alpha=0.05$ :

a. If the probability is $>\alpha 0.05$ then $\mathrm{H}_{0}$ is accepted and $\mathrm{H}_{\mathrm{a}}$ is rejected, it means that Current Ratio has no effect on Return (Return on Asset Ratio ).

b. If $<\alpha 0.05$ then $\mathrm{H}_{0}$ is rejected and the probability $\mathrm{H}_{\mathrm{a}}$ is accepted, meaning Current Asset (Ratio ) has an effect on profit (Return on Asset Ratio ). 
3. Hypothesis 3 or line test $3(\mathrm{p} 3)$

$\mathrm{H}_{0}=$ Debt ( Debt to Asset Ratio ) has no effect on earnings ( Return on Asset Ratio ) at JII company in Indonesia Stock Exchange Year 2012-2014.

$\mathrm{H}_{\mathrm{a}}=$ Debt ( Debt to Asset Ratio ) effect on profit ( Return on Asset Ratio ) at JII company in Indonesia Stock Exchange Year 2012-2014.

Criteria for probability decision making (significance) with $\alpha=0.05$ :

a. If the probability is $>\alpha 0.05$ then $\mathrm{H}_{0}$ is accepted and $\mathrm{H}_{\mathrm{a}}$ is rejected, it means Debt (Debt to Asset Ratio ) has no effect on profit (Return on Asset Ratio ).

b. If the probability is $<\alpha 0.05$ then $\mathrm{H}_{0}$ is rejected and $\mathrm{H}_{\mathrm{a}}$ is accepted, it means Debt ( Debt to Asset Ratio ) effect on profit (Return on Asset Ratio ).

4. Hypothesis 4 or line test $4(\mathrm{p} 4)$

$\mathrm{H}_{0}=$ current assets (Current Ratio) does not affect the profit (Return on Assets Ratio) through debt (Debt to Asset Ratio) at JII company in Indonesia Stock Exchange Year 2012 to 2014.

$\mathrm{H}_{\mathrm{a}}=$ Current Ratio affects the return on Asset Ratio through debt ( Debt to Asset Ratio ) in JII company in Indonesia Stock Exchange Year 2012-2014.

Criteria of decision making by comparing the value of $t$ arithmetic with $t$ table:

a. If $\mathrm{t}$ arithmetic $<\mathrm{t}$ table then $\mathrm{H}_{0}$ accepted and $\mathrm{H}_{\mathrm{a}}$ rejected, meaning Current assets ( Ratio ) does not affect the profit ( Return on Asset Ratio) through debt ( Debt to Asset Ratio ).

b. If $\mathrm{t}$ arithmetic $>\mathrm{t}$ table then $\mathrm{H}_{0}$ rejected and $\mathrm{H}_{\mathrm{a}}$ accepted, meaning Asset Current ( Current Ratio ) influence on profit ( Return on Asset Ratio ) through debt ( Debt to Asset Ratio ) (Ghozali, 2013: 255-259).

\section{Results and Discussion}

(Ghozali, 2013; 19) Descriptive statistics provide an overview or description of data viewed from mean values (mean, standard deviation, variant, maximum, minimum, sum, range , kurtosis, and skewness ).

Table 3. Descriptive statistics

\begin{tabular}{|l|r|r|r|r|r|}
\hline & \multicolumn{1}{|c|}{ N } & Minimum & Maximum & \multicolumn{1}{c|}{ Mean } & Std. Deviation \\
\hline ROA & 42 & 2,86 & 71,51 & 15,7721 & 12,16276 \\
DAR & 42 &, 14 & 1,21 &, 3976 &, 19880 \\
CR & 42 & 45,00 & 614,81 & 222,7650 & 136,23570 \\
Valid N (listwise) & 42 & & & & \\
\hline
\end{tabular}

The standard deviation value is lower than the mean, which means the data has a low data 
rate.

\section{Classic assumption test}

Normality test

\section{Normality Testing Hypothesis 1}

Test results of normality test showed that Kolmogrov-Smirnov $\mathrm{Z}$ of 0.751 and Asymp value.Sig. (2-tailed) of 0.626 or $62.6 \%$. The signification number is greater than 0.05 or $5 \%$. This means that the model used in Hypothesis 1 research is feasible.

\section{Testing Normality of Hypothesis 2 and Hypothesis 3}

The result of normality test showed that Kolmogrov-Smirnov $\mathrm{Z}$ equal to 0.848 and Asymp value.Sig. (2-tailed) of 0.469 or $46.9 \%$. The significance is greater than 0.05 or $5 \%$. This means that the model used in Hypothesis 2 and Hypothesis 3 is feasible.

\section{Autocorrelation Test}

\section{Autocorrelation Testing Hypothesis 1}

Test results of autocorrelation test obtained DW value sebesr 2,195. Since the DW value of 2.195 is greater than the upper limit of (du) 1.5534 and less than $4-\mathrm{du}(4-1.5534=2.4466)$, it can be concluded that we can not reject $\mathrm{H}_{0}$ stating that there is no positive or negative autocorrelation or it can be concluded there is no autocorrelation.

\section{Autocorrelation Testing Hypothesis 2 and Hypothesis 3}

Test results of autocorrelation test obtained DW value of 1.508. Since the DW value of 1.508 is smaller than the upper limit of (du) 1.6061 and greater than the lower limit (dl) 1.4073, it can be concluded that we can not make a decision whether $\mathrm{H}_{0}$ is acceptable or $\mathrm{H}_{\mathrm{a}}$ accepted or can be inferred there is no positive autocorrelation.

\section{Heterocedasticity Test}

\section{Heterocedasticity Testing Hypothesis 1}

The result of test of glejser test obtained by significance value equal to 0,069 . Because the significance value of 0.069 is greater than 0.05 , it can be concluded that there is no heterokedastisity in the regression model. So this regression model is feasible to be used in testing Hypothesis 1.

\section{Heterocedasticity Testing Hypothesis 2 and Hypothesis 3}

The result of testing of glejser test of current ratio value to profit (Return on Asset Ratio ) equal to 0,326 and Debt to Asset Ratio value to profit (Return on Asset Ratio ) equal to 0,000.Therefore, the value of current ratio of Return on Asset Ratio of 0.326 is greater than 0.05 , it can be concluded that there is no heterokedastisity in the regression model.So this regression model is feasible to be used in testing Hypothesis 2 , while Debt to Asset Ratio to earnings ( Return on Asset Ratio ) equal to 0.000 less than 0,05, hence can be concluded that happened heterokedastisitas on regression model .So this regression model is not feasible for use in testing Hypothesis 3. The researcher transformed the variable into the square root of DAR debt $(\sqrt{D A R})$ Result of testing of gross root square root of DAR debt obtained by significance value equal to 0,676 . Because the significance value of 0.676 is greater than 0.05 , it can be concluded that there is no heterokedastisity in the regression model.So this 
regression model is feasible to be used in testing Hypothesis 3 .

\section{Multicollinearity Test}

The result of multicollinearity test is VIF value far from 10. This means there is no multicollinear in regression in Hypothesis 2 of Hypothesis 3 research .

\section{Path Analysis}

Based on the concepts and theories that have been presented, researchers use debt ( Debt to Asset Ratio ) as intervening variable between current assets (Current Ratio ) with profit (Return on Asset Ratio ).

\section{Path Analysis 1 (p1)}

Path analysis 1 (p1) is with the endogenous variable (Yt) Debt ( Debt to Asset Ratio ) and the exogenous variable (X) Current Ratio obtained the following result,

$$
\text { 1. } D A R=0,591-0,001 C R+0,805
$$

2. Coefficient value 0,591 indicates that if current assets (Current Ratio ) is 0 then Debt to Asset Ratio is 0,591 .

3. The value of path coefficient $1(\mathrm{p} 1)$ is -0.001 indicates that any increase of 1 unit in Current Ratio will cause Debt to Asset Ratio to decrease by 0.001 unit, indicating that the higher Current Ratio, ( Debt to Asset Ratio will be lower.

\section{Path 2 Analyzer (p2)}

Path analysis 2 (p2) that is with variable endogenous profit ( Return on Asset) and exogenous variable of current assets ( Current Ratio ) obtained by following result,

1. $R O A=-5,534+0,030 C R+0,876$

2. -5.534 coefficient values indicate that if the current assets (Current Ratio) is 0 then return (Return on Assets) worth -5.534.

3. The value of path coefficient 2 (p2) is 0,030 indicates that every increase of 1 unit in Current Ratio will cause profit ( Return on Asset ) to increase equal to 0,030 unit, indicating that the higher of Current Ratio ( earn Ratio ) Return on Asset ) will be higher too.

\section{Path 3 Analyzer (p3)}

Path 3 (p3) analysis with endogenous variable ( Return on Asset) and Debt to Asset Ratio obtained the following result,

1. $R O A=-5,534+36,653 D A R+0,876$

2. The coefficient value of -5.534 indicates that if debt ( Debt to Asset Ratio value is 0 then profit ( Return on Asset ) is worth -5,534.

3. The coefficient value of line 3 (p3) is 36.653 indicates that every increase of 1 unit in debt (Debt to Asset Ratio ) will cause the profit ( Return on Asset) rose by 36.653 units, indicating that the higher debt ( Debt to Asset Ratio ) (Return on Asset) will be higher too.

\section{Line 4 Analysis (p4)}

Path analysis $4(\mathrm{p} 4)$ is with endogenous variable (Y) profit (Return on Assets), intervening variable (Y1) Debt (Debt to Asset Ratio) and exogenous (X) of current assets (Current Ratio) obtained results which is summarized in the linear model summary in table 4 below, 


\begin{tabular}{|c|c|c|c|}
\hline Variabel & $\begin{array}{c}\text { Pengaruh } \\
\text { Langsung } \\
\text { CR } \rightarrow \text { ROA }\end{array}$ & $\begin{array}{c}\text { Pengaruh Tidak } \\
\text { Langsung } \\
\text { CR } \rightarrow \text { DAR } \rightarrow \text { ROA }\end{array}$ & $\begin{array}{c}\text { Peagaruh Total } \\
\text { (Langsung + Tidal } \\
\text { Langsung }\end{array}$ \\
\hline CR & 0,030 & $\begin{array}{c}-0,001 \times 36,653= \\
-0,036653\end{array}$ & $\begin{array}{c}0,030+-0,036653= \\
-0,006653\end{array}$ \\
\hline
\end{tabular}

Analysis of line 4 (p4) concluded that influence current assets ( Ratio ) to profit ( Return on Asset ) through debt ( Debt to Asset Ratio ) obtained equation as follows:

1. $\mathrm{Y}=\beta_{0}+\beta_{2} \mathrm{X}_{1}+\beta_{3} \mathrm{Y}_{1}+\beta_{4} \mathrm{X}_{1} \mathrm{Y}_{1}+\mathrm{e}_{2}$

$R O A=-5,534+0,030 \mathrm{CR}+36,653 \mathrm{DAR}-0,036653+0,876$

2. The value of line coefficient $4(\mathrm{p} 4)$ of -0.0006653 shows any increase in current assets ( debt ratio ) and debt ( Debt to Asset Ratio ) it will cause profit (Return on Asset ) decreased by 0.0006653 units.

\section{Hypothesis testing}

Hypothesis test ( $\mathrm{t}$ test) is done to determine whether the dependent variable (Y) has an effect on independent variable $(\mathrm{X})$ and (Sobel test) to know the indirect effect of independent variable $(\mathrm{X})$ to the dependent variable $(\mathrm{Y})$ through the intervening variable ) used in this study.

\section{Hypothesis Testing 1}

The researcher uses phase of hypothesis determination, quantitative data processing with spss, and compare probability value (significance) with $\alpha=0,05$. The hypothesis is defined as:

$\mathrm{H}_{0}=$ Current Ratio does not affect Debt to Asset Ratio in JII Company in Indonesia Stock Exchange Year 2012-2014.

$\mathrm{H}_{\mathrm{a}}=$ Current Ratio ( Debt to Asset Ratio ) in JII Company in Indonesia Stock Exchange Year 2012-2014.

Data management using spss, obtained probability value 0.000 next probability value compared with provisions:

If the probability is $>\alpha 0.05$ then $\mathrm{H}_{0}$ is accepted and $\mathrm{H}_{\mathrm{a}}$ is rejected

If the probability is $<\alpha 0.05$ then $\mathrm{H}_{0}$ is rejected and $\mathrm{H}_{\mathrm{a}}$ is accepted

Based on the calculation, the probability value of 0.000 is smaller than $\alpha 0.05$ then $\mathrm{H}_{0}$ is rejected and $\mathrm{H}_{\mathrm{a}}$ is accepted.Can be disimpu lkan that current assets ( Current Ratio ) have a significant effect on debt ( Debt to Asset Ratio ).

\section{Hypothesis Testing 2}

The researcher uses phase of hypothesis determination, quantitative data processing with spss, and compare probability value (significant si) with $\alpha=0,05$. The hypothesis is defined as:

$\mathrm{H}_{0}=$ Current assets ( Current Ratio ) has no effect on earnings ( Return on Asset Ratio ) at JII company in Indonesia Stock Exchange Year 2012-2014.

$\mathrm{H}_{\mathrm{a}}=$ Current assets ( Current Ratio ) effect on profit ( Return on Asset Ratio ) at JII company in Indonesia Stock Exchange Year 2012-2014.

Data management using spss, obtained probability value 0,059 then probability value compared with provision:

If the probability is $>\alpha 0.05$ then $\mathrm{H}_{0}$ is accepted and $\mathrm{H}_{\mathrm{a}}$ is rejected 
If the probability is $<\alpha 0.05$ then $\mathrm{H}_{0}$ is rejected and $\mathrm{H}_{\mathrm{a}}$ is accepted

Based on the calculation, the probability value of 0.059 is greater than $\alpha 0.05$ then $\mathrm{H}_{0}$ is accepted and $\mathrm{H}_{\mathrm{a}}$ is rejected.Can be concluded that current assets ( Current Ratio ) no significant effect on profit ( Return on Asset Ratio ).

\section{Hypothesis Testing 3}

The researcher uses phase of hypothesis determination, quantitative data processing with spss, and compare probability value (significance i) with $\alpha=0,05$. The hypothesis is defined as:

$\mathrm{H}_{0}=$ Debt ( Debt to Asset Ratio ) has no effect on earnings ( Return on Asset Ratio ) at JII company in Indonesia Stock Exchange Year 2012-2014.

$\mathrm{H}_{\mathrm{a}}=$ Debt ( Debt to Asset Ratio ) effect on profit ( Return on Asset Ratio ) at JII company in Indonesia Stock Exchange Year 2012-2014.

Data management using spss, obtained probability value 0,001 then probability value compared with provision:

If the probability is $>\alpha 0.05$ then $\mathrm{H}_{0}$ is accepted and $\mathrm{H}_{\mathrm{a}}$ is rejected

If the probability is $<\alpha 0.05$ then $\mathrm{H}_{0}$ is rejected and $\mathrm{H}_{\mathrm{a}}$ is accepted

Based on the calculation, the probability value of 0.001 is smaller than $\alpha 0.05$ then $\mathrm{H}_{0}$ is rejected and $\mathrm{H}_{\mathrm{a}}$ is accepted.It can be concluded that Debt (Debt to Asset Ratio) has a significant effect on profit (Return on Asset Ratio).

\section{Hypothesis Testing 4}

The researcher uses phase of hypothesis determination, quantitative data processing with sobel test done by calculating standard error from indirect effect coefficient and calculate $t$ value of statistic, and compare $t$ value with $t$ table.The hypothesis is defined as:

$\mathrm{H}_{0}=$ current assets (Current Ratio) does not affect the profit (Return on Assets Ratio) through debt (Debt to Asset Ratio) at JII company in Indonesia Stock Exchange Year 2012 to 2014.

$\mathrm{H}_{\mathrm{a}}=$ Current Ratio affects the return on Asset Ratio through Debt to Asset Ratio at JII Company in Indonesia Stock Exchange Year 2012-2014.

Management of quantitative data with the test conducted by calculating the standard error of indirect effect coefficient and calculate the value of $t$ statistics, obtained value $t$ arithmetic $=$ 3.4578 then the value of $t$ arithmetic compared with the value of $t$ table with the provisions:

If $\mathrm{t}$ arithmetic $<\mathrm{t}$ table then $\mathrm{H}_{0}$ accepted and $\mathrm{H}_{\mathrm{a}}$ rejected

If $\mathrm{t}$ arithmetic $>\mathrm{t}$ table then $\mathrm{H}_{0}$ rejected and $\mathrm{H}_{\mathrm{a}}$ accepted

Based on the calculation, the value of $t$ arithmetic of 3.4578 is greater than $t$ table with a significance level of 0.005 of 2.02269 , it can be concluded that the current assets ( Current Ratio ) significant effect on profit ( Return on Asset Ratio) through debt ( Debt to Asset Ratio ).

\section{Interpretation of Results}

\section{Effect of Current Assets (Current Ratio) Against Debt (Debt to Asset Ratio)}

Based on the results of research on the impact of current assets (Current Ratio) to debt (Debt to Asset Ratio) is a significant and negative, indicating higher current assets (Current Ratio), 
the Debt (Debt to Asset Ratio) will be lower.In accordance with research Indriani (2009) and Aditya (2006) which shows there is significant and negative influence between liquidity (current assets) to solvency (debt), meaning the higher the value of current assets the lower the debt value.This is in accordance with the theory expressed by Kasmir $(2014 ; 134)$ the ratio of current assets is a ratio to measure the ability of a company to pay short-term liabilities (debt) that are due at the time of collection. Increasing the value of current assets ( Current Ratio ) will reduce the debt value ( Debt to Asset Ratio ), in other words current assets ( Ratio ) significant and negative to debt (Debt to Asset Ratio ).

\section{Influence of Current Ratio on Return (Return on Asset Ratio)}

Based on the results of research the influence of current assets (Current Ratio) on profit (Return on Asset) is not significant and positive, shows the higher current assets ( Current Ratio ) then the profit (Return on Asset) also higher.Current assets (Ratio) does not significantly affect earnings (Return on Asset Ratio) because there are two companies that become research samples in Jakarta Islamic Index that is PT.Astra Argo Lestari Tbk. and PT. Unilever Indonesia Tbk. when viewed from its financial statements of 2012-2014 the company has a higher current debt than current assets. According to the theory of Riyanto (1995) in Nugroho (2011: 31) healthy companies have current assets of not less than 2: 1, meaning that current assets should be well above current liabilities.

On the other hand profit is affected by debt. In accordance with the theory of Van Horne and Machowicz (2005: 313) in his book the principles of financial management which says that profitability is inversely proportional to debt.John $(2005 ; 122)$ explains the greater the proportion of debt to the capital structure, the higher the fixed burden and repayment commitments incurred.These results are supported by research conducted by Yesi (2013) and Herdinanto (2013) with the results of significant and negative debt to earnings.

\section{Effect of Debt (Debt to Asset Ratio) against earnings (Return on Assets Ratio)}

Based on the results of research debit to debt ratio ( Return on Asset ) is significant and positive, indicating the higher debt ( Debt to Asset Ratio ) then the profit (Return on Asset) will be higher too.In accordance with the theory proposed by Sawir (2001) in Marina (2016; 7) which states that debt financing can be used to increase shareholder returns (dividends). Increase in dividends is an indication of an increase in profits, but debt financing has a risk of increasing losses in the bleak times if the debt funds are not accompanied by good pengelolahan.

\section{Effect of Current Assets (Current Ratio) against earnings (Return on Assets Ratio) Through Debt (Debt to Asset Ratio)}

Based on the results of research on the impact of current assets (Current Ratio) to profit (Return on Assets) through debt (Debt to Asset Ratio) is a significant and negative, showed any increase in current assets (Current Ratio) and debt (Debt to Asset Ratio) will lead to profit ( Return on Asset ) down.In accordance with Rahmawati ( 2011: 24) stated the greater the current assets, indicating the greater the ability of the company to meet its short-term obligations, meaning that the company places substantial funds on current assets. The placement of large funds on the asset side has two effects. On the one hand, the company's debt gets better, on the other hand the company loses the opportunity to earn extra profit, 
because funds for investment, are reserved to meet the debt.

In line with Syafri (2005) in Marina (2016, 24-25) stating that the solvency ratio describes the company's ability to pay its long-term liabilities or liabilities if the company is liquidated. The increasing debt has an impact on the profit earned. With the higher interest cost, the profit decreases (partially used to pay interest).

\section{Conclusions and Recommendations}

After testing in this research, it can be concluded as follows:

1) Current assets (Current Ratio) a significant effect on the debt (Debt to Asset Ratio) at JII company in Indonesia Stock Exchange Year 2012 to 2014.

2) Current assets ( Ratio ) has no significant effect on Return on Asset Ratio in JII company in Indonesia Stock Exchange Year 2012-2014.

3) Debt ( Debt to Asset Ratio ) has a significant effect on Return on Asset Ratio in JII company in Indonesia Stock Exchange Year 2012-2014.

4) Current assets ( Ratio ) has a significant effect on profit ( Return on Asset Ratio ) through debt ( Debt to Asset Ratio ) in JII company in Indonesia Stock Exchange Year 2012-2014.

\section{For Further Researchers}

Further analyzes of the behavior of current assets (cash, accounts receivable, inventory) in JII corporations that impact on profit, because JII covers the agriculture, trade, industry, investment and services sectors.

\section{For Company Owners}

For company management to consider the following:

1. Reduce supply by increasing inventory turnover.

2. Minimize receivables by reducing receivable turnover.

3. Retained earnings are more likely to be used for debt financing, with debt considerations increasing the volume of earnings that impact on earnings. Because if the company uses more debt than its own capital it will have an impact on the decline in profits.

\section{For Investors}

For investors who invest more paying debt because of debt has a larger contribution than the current assets. The higher the debt can be indicated by the current asset is also high because the asset is the value of the company that can become the debt guarantee for the operational payments of the company. Debt policy plays an important role in corporate growth as a potential external funding source. The lower the debt policy, the higher the profitability of the company and the higher the dividend.

\section{For Leaders and Policy Makers}

To improve profitability, company management uses financial analysis in investment decision making by considering the tax benefits on debt and on cash trends mingling with opportunity costs .

\section{References}

Aditya, J. (2006). Empirical Study Factors Affecting Capital Structure in Manufacturing 
Companies in Jakarta Stock Exchange Year 2000-2003. thesis Department of Management Faculty of Economics, University Islam Indonesia Yogyakarta, Yogyakarta.

Afriyanti, M. (2011). Influence Analysis of Current Ratio, Total Asset Turnover, Debt to Equity Ratio, Sales and Size to ROA (Return on Asset ). thesis S1 Economics Faculty of Economics, Diponegoro University, Semarang.

Arikunto, S. (2010). Research Procedure A Practice Approach, Rineka Cipta, Jakarta.

Barus, air conditioning. (2013). Analysis of Factors Affecting Profitability at Manufacturing Companies Listed on the Stock Exchange. Journal of Microscopic Economic Entrepreneurship, 3(2).

Mora, R. I. (2003). Syari'ah Capital Market in Indonesia: Initiating the Shariah Capital Market from Practice Aspects, Ministry of Religious Affairs, Jakarta.

Dewi, N. K. V. C. (2015). The Effect of LDR, LAR, DER and CR on ROA in banking companies listed on BEI 2011-2013. e- Journal Bisma Ganesha University of Management Department, 3.

Fahmi, I. (2011). Financial Statement Analysis, Alfabeta, Bandung.

Ghofron, S., 2005, Shariah Financial and Investment System, Renaisia, Jakarta.

Ghozali, I. (2009). Econometrics.Theory, Concepts, and Applications with SPSS 17 .Semarang: Diponegoro University Publishing Agency .

Ghozali, M. I. (2013). Application of Multivariate Analysis with SPSS Program, Diponegoro University Publishing Agency, Semarang.

Hanafi, M. M., \& Abdul, H. (2014). Financial Statement Analysis, Issue 4, Print 3, UPP STIM YKPN, Yogyakarta.

Hartono. (2015). The Influence of Current Ratio and Debt to Equity Ratio on Profitability in Metal and Similar Sector Manufacturing Companies Listed on Indonesia Stock Exchange Period 2009-2013. Journal of Microscope Economic Entrepreneur, 5(01).

Herdinanto, F. (2013). The Influence of Debt to Total Asset Ratio and Current Ratio to Return On Asset, on Pharmaceutical Company Listed on Indonesia Stock Exchange Year 2006-2012. said Department of Management Faculty of Economics and Business, Trunojoyo University, Madura.

Huda, N., \& Nasution, M. E. (2007). Investments in the Shariah Capital Market .Kencana, Jakarta.

Indriani, A. (2009). Influence Analysis of Current Ratio, Sales Growth, Return On Asset, Retainet Earning and Size Against Debt to Equity Ratio in Manufacturing Company Listed on Indonesia Stock Exchange Year 2005-2007. Diponegoro University, Semarang.

Isna. (2014). Quantitative Research is Definition and Definition of Qualitative Research.a

James, C., Van, H., \& John, M. M. (2005). Principles of Financial Management (Book 2), 12th Edition, Salemba Four, Jakarta.

John, J.W. (2005). Financial Statement Analysis, 2, Salemba Four, Jakarta.

Cashmere. (2014). Financial Statement Analysis, 7th Print, Publisher PT Raja Grafindo Persada, Jakarta. 
Solemn, W. B. (2014). Impact of Liquidity \& Solvency on Profitability Chemical Sector of Pakistan. Journal Economics Management Innovation , 6(3).

Kuncoro, M. (2004). Quantitative Method, UPP AMP YKPN, Yogyakarta.

Kurniati, W. (2007). The Influence of Ownership Structure on Corporate Debt Policy. Diponegoro University's Thesis, Semarang.

Latifah, L. (2009). Factor Analysis Affecting Dividend Payout Ratio in Companies Registered in Jakarta Islamic Index (JII) Year 2003-2007. Thesis S1 Islamic Economics Faculty of Economics Syari'ah, Walisongo State Islamic Institute, Semarang.

Mansur, M. K. (2015). The Effect of Liquidity and Solvency on Provitability. thesis S1 Economics Faculty of Economics and Islamic Business, Walisongo State Islamic University, Semarang.

Marina, D. (2016). The Effect of Solvency on Dividends Through Profitability at LQ45 Company 2011-2013 in Indonesia Stock Exchange," said the Department of Management Faculty of Economics, University of Muhammadiyah Gresik, Gresik.

Munawir, S. (2002). Financial Statement Analysis, Issue 2, BPFE, Yogyakarta.

Nugroho, E. (2011). Analysis of Liquidity Influence, Sales Growth, Working Capital Turnover, Company Size and Leverage to Company Profitability (Study on Manufacturing Companies Listed on Indonesia Stock Exchange in 2005-2009. thesis S1 Management Faculty of Economics, Diponegoro University, Semarang.

Nursalam. (2013). Research Methodology of Nursing Science, 3rd Edition, Salemba Medika, Jakarta.

Rahmawati, E. (2011). The Influence of Current Ratio, ROA, Debt Policy and Firm Size on Dividend Policy by Using Logistic Regression. said Department of Management Faculty of Economics and Business, Syarif Hidayatullah State Islamic University, Jakarta.

Ratno, A. (2014). Financial Statement and Financial Analysis, Piramedia, Semarang.

Reni, N. (2014). The Influence of Gross Profit Margin, Return on Equity, Earning Per Share and Current Ratio to Capital Structure (DER) in Manufacturing Companies Listed on Indonesia Stock Exchange 2010-2012. thesis S1 Accounting Faculty of Economics, University Nusantara PGRI, Kediri.

Riyadi. S. (2006). Banking Assets an Liability Management, Faculty of Economics, University of Indonesia, Jakarta.

$\begin{array}{lllll}\text { Sarah, } & \text { Z. } & \text { (2012). } & \text { Statistics, } & \text { Retrieved }\end{array}$ http://zaneta9bp2.blogspot.co.id/p/populasi-sampel.html

Sartono, A. (2010). Financial Management "Theory and Applications (4th ed.) BPFE, Yogyakarta.

Sarwono, J., \& Suhayati, L. (2010). Accounting Research Using SPSS, Graha Ilmu, Yogyakarta.

Setiawan, E. (2015). Influence of Current Ratio , Inventory Turnover, Debt to Equity Ratio, Total Turnover Assets, Sales, and firm Size to ROA in Food and Beverage Companies Terdafatar at Indonesia Stock Exchange (BEI) Period 2010-2013. thesis Department of Accounting Faculty of Economics, Raja Ali Haji Maritime University, Riau. 
Sholihudin, M. (2006). Institute for Economics and Islamic Finance, Muhammadiyah University Press, Surakarta.

Stella. (2009). Influence of Price to Earning Ratio, Debt to Equity Ratio, Return On Assets and Price to Book Value on Stock Market Price. Journal of Business and Accounting, 11(2), , 97-106.

Sugiyono. (2014). Qualitative Quantitative Research Methods and $R \& D$, Alfabeta, Bandung.

Supangat, A. (2010). Statistics: In Descriptive, Inferential, and Nonparametric Studies , Kencana.Jakarta.

Supardi, U. S. (2013). Statistics Application in Comprehensive Statistical Concept Research, Revised Edition, Change Publication, Jakarta.

Single, A. W. (2010). Principles of Financial Statement Analysis. Harvarindo, Jakarta.

Yarti, M. (2011). The Effect of Solvency on Liquidity of PT Bank Muamalat Indonesia Tbk Year 1993-2009. thesis Department S1 Muamalat (Islamic Economics) Faculty of Sharia and Law, State Islamic University Syarif Hidayatullah, Jakarta.

Yesi, H. (2013). The Influence of Current Ratio, Net Working Capital Turnover and Debt to Asset Ratio to ROA in Property and Real Estate Companies Listed on BEI Period 2008-2012. thesis S1 Management Faculty of Economics, Raja Ali Haji University, Riau.

Yulianti. (2014). Analysis of the Influence of Macroeconomic Fundamentals on Stock Return of Property Sector Index in Indonesia Stock Exchange Year 2007-2013. said Department of Management Faculty of Economics and Business, Diponegoro University, Semarang.

\section{Copyright Disclaimer}

Copyright for this article is retained by the author(s), with first publication rights granted to the journal.

This is an open-access article distributed under the terms and conditions of the Creative Commons Attribution license (http://creativecommons.org/licenses/by/3.0/). 